\title{
Effect of low-level laser therapy on bisphosphonate-treated osteoblasts
}

\author{
Sang-Hun Shin ${ }^{1 *}$, Ki-Hyun Kim ${ }^{1 \dagger}$, Na-Rae Choi ${ }^{1 \dagger}$, In-Ryoung Kim² ${ }^{2}$ Bong-Soo Park², Yong-Deok Kim', Uk-Kyu Kim
} and Cheol-Hun $\mathrm{Kim}^{3}$

\begin{abstract}
Background: This study investigates the effect of alendronate-treated osteoblasts, as well as the effect of low-level laser therapy (LLLT) on the alendronate-treated osteoblasts. Bisphosphonate decreases the osteoblastic activity. Various treatment modalities are used to enhance the bisphosphonate-treated osteoblasts; however, there were no cell culture studies conducted using a low-level laser.

Methods: Human fetal osteoblastic (hFOB 1.19) cells were treated with $50 \mu \mathrm{M}$ alendronate. Then, they were irradiated with a $1.2 \mathrm{~J} / \mathrm{cm}^{2}$ low-level Ga-Al-As laser $\left(\lambda=808 \pm 3 \mathrm{~nm}, 80 \mathrm{~mW}\right.$, and $80 \mathrm{~mA}$; spot size, $1 \mathrm{~cm}^{2}$; NDLux, Seoul, Korea). The cell survivability was measured with the MTT assay. The three cytokines of osteoblasts, receptor activator of nuclear factor $\mathrm{KB}$ ligand (RANKL), osteoprotegerin (OPG), and macrophage colony-stimulating factor (M-CSF) were analyzed.

Results: In the cells treated with alendronate at concentrations of $50 \mu \mathrm{M}$ and higher, cell survivability significantly decreased after $48 \mathrm{~h}(p<0.05)$. After the applications of low-level laser on alendronate-treated cells, cell survivability significantly increased at $72 \mathrm{~h}(p<0.05)$. The expressions of OPG, RANKL, and M-CSF have decreased via the alendronate. The RANKL and M-CSF expressions have increased, but the OPG was not significantly affected by the LLLT.

Conclusions: The LLLT does not affect the OPG expression in the hFOB cell line, but it may increase the RANKL and M-CSF expressions, thereby resulting in positive effects on osteoclastogenesis and bone remodeling.
\end{abstract}

Keywords: Bisphosphonate, Osteoblasts, Low-level laser therapy (LLLT), BRONJ

\section{Background}

Bisphosphonates (BPs) are a group of medications that are known to be effective for inhibiting bone resorption. They have been used in clinical settings for over 30 years [1] in patients with multiple myeloma, metastatic skeletal disease, and hypercalcemia of malignancy. BPs are also effective in patients with Paget's disease of bone and osteoporosis [2].

First described by Marx in 2003, bisphosphonate-related osteonecrosis of the jaw (BRONJ) is a side effect of BP use in dentistry [3]. Many authors have hypothesized that $\mathrm{BRONJ}$ is related to the oversuppression of bone turnover caused by BP usage [4]. Subramaian et al. [5] introduced a

\footnotetext{
* Correspondence: ssh8080@pusan.ac.kr

Ki-Hyun Kim and Na-Rae Choi are co-first authors.

${ }^{\dagger}$ Equal contributors

'Department of Oral and Maxillofacial Surgery, School of Dentistry, Pusan

National University, Beomeo, Mulgeum, Yangsan 626-770, Republic of Korea Full list of author information is available at the end of the article
}

hypothesis that focuses on a defective remodeling process secondary to weakened synergism among the key cell types that interact during bone remodeling, including osteoblasts, osteoclasts, osteocytes, and bone lining cells.

At the cellular level, BPs have been known to act directly or indirectly on the osteoclasts. Decreased osteoclastogenesis can occur either directly on osteoclast precursors or indirectly by stimulating the osteoblasts to produce an inhibitor of osteoclast formation. The inhibition of the osteoblast-osteoclast pathway is an important component of the bisphosphonate activity [6].

The bone is continuously destroyed and reformed by a strictly regulated equilibrium between osteoblastic bone formation and osteoclastic resorption. During this process, osteoblasts stimulate bone formation and mediate osteoclast differentiation and function via cell-to-cell contact with osteoclast precursors. The roles of various substances 
related to the bone resorption process were recently clarified. These substances include the receptor activator of nuclear factor $\kappa B$ ligand (RANKL), osteoprotegerin (OPG), and macrophage colony-stimulating factor (M-CSF).

Researchers have focused on additional methods to support healing in the management of BRONJ, including medications and surgical procedures. An additional supporting method is low-level laser therapy (LLLT) [7]. Yaakobi et al. [8] reported the curative effects of LLLT in bone regeneration. In vitro laser biostimulation studies have also been performed with osteoblasts or osteoblastlike cells. Dörtbudak et al. [9] reported that LLLT has stimulatory effects on the bone matrix formation in osteoblast cell culture. However, the effects of LLLT on bisphosphonate-treated osteoblasts are not well known.

This study investigated the expressions of RANKL, OPG, and M-CSF in bisphosphonate-treated osteoblasts, as well as the effects of LLLT on bisphosphonate-treated osteoblasts, in order to provide an experimental basis for BRONJ treatment.

\section{Methods}

\section{Cell culture and treatment with alendronate}

A human fetal osteoblast (hFOB 1.19) cell line was purchased from the American Type Culture Collection (ATCC; Rockville, MD, USA). The hFOB 1.19 cells were cultured at $34{ }^{\circ} \mathrm{C}$ with $5 \% \mathrm{CO}_{2}$ in an incubator. The culture medium was a $1: 1$ mixture of Dulbecco/Vogt modified Eagle's minimal essential medium (DMEM) and F12 (Invitrogen, USA) supplemented with 10\% fetal bovine serum (Invitrogen). Cells were cultured on culture dishes and/or in several types of wells for $24 \mathrm{~h}$, after which the original medium was removed and the cells were washed with phosphate-buffered saline (PBS). Alendronate (Sigma, St. Louis, MO, USA) stock solution was added to the fresh medium in order to attain drug concentrations of $0,25,50,100,250,500$, and $1000 \mu \mathrm{M}$.

\section{Low-level laser irradiation}

After the alendronate treatment, laser irradiation was performed with a gallium-arsenide-aluminum (Ga-AlAs) laser $(\lambda=808 \pm 3 \mathrm{~nm}$; $80 \mathrm{~mW}$; $80 \mathrm{~mA}$; spot size, $1 \mathrm{~cm}^{2}$; NDLux; Seoul, Korea) in the dark to eliminate the influence of other light sources. Laser energy was provided to the cells in continuous mode and vertical direction of each well. The laser handpiece was fixed, and the plate was moved to irradiate one well at a time ( $5 \mathrm{~cm}$ above the bottom of the culture plate). Laser was applied for a duration of $15 \mathrm{~s}$ for each well at 0,24 , and $48 \mathrm{~h}$. After $72 \mathrm{~h}$, the total irradiated energy was $3.6 \mathrm{~J} / \mathrm{cm}^{2}$.

\section{Cell survivability assay}

A total of $1 \times 10^{4}$ cells were seeded in a 96-well plate, incubated for $24 \mathrm{~h}$, and treated with alendronate at various concentrations and time points with and without lowlevel laser irradiation. Then, the cells were treated with $500 \mu \mathrm{g} / \mathrm{ml}$ of MTT stock solution and incubated at $34{ }^{\circ} \mathrm{C}$ in a $5 \% \mathrm{CO}_{2}$ atmosphere for $4 \mathrm{~h}$. The medium was aspirated, and the formazan crystals were dissolved in DMSO. Cell survivability was monitored on an ELISA reader (Tecan, Männedorf, Switzerland) at an excitation emission wavelength of $570 \mathrm{~nm}$.

\section{Western blot analysis}

The Western blot analysis was performed by using mouse sRANKL, OPG, M-CSF, and rabbit polyclonal antihuman GAPDH antibody (Santa Cruz Biotechnology, Santa Cruz, CA, USA).

The cells were washed twice with ice-cold PBS and centrifuged at $2000 \mathrm{rpm}$ for $10 \mathrm{~min}$. The total cell proteins were lysed with a RIPA buffer (300 mM $\mathrm{NaCl}, 50 \mathrm{mM}$ Tris- $\mathrm{HCl}$ [pH 7.6], 0.5\% TritonX-100, $2 \mathrm{mM}$ PMSF, $2 \mu \mathrm{g} / \mathrm{ml}$ aprotinin, and $2 \mu \mathrm{g} / \mathrm{ml}$ leupeptin) and incubated at $4{ }^{\circ} \mathrm{C}$ for $1 \mathrm{~h}$. The lysates were centrifuged at $14,000 \times g$ at $4{ }^{\circ} \mathrm{C}$ for $15 \mathrm{~min}$, and sodium dodecyl sulfate (SDS) and sodium deoxycholic acid $(0.2 \%$ final concentration) were added. The protein concentrations of the cell lysates were determined by means of a Bradford protein assay (Bio-Rad, Richmond, CA, USA), and the bovine serum albumin (BSA) was used as the protein standard. A $20 \mu \mathrm{g}$ protein sample from each well was separated and loaded onto a $10 \%$ SDS-PAGE. The gels were transferred to a PVDF (Amersham GE Healthcare, Little Chalfont, UK), and they reacted to each antibody. Immunostaining with antibodies was performed by using a Super Signal West Femto enhanced chemiluminescent substrate and detected by Alpha Imager HP (Alpha Innotech, Santa Clara, CA, USA). Equivalent protein loading was confirmed by Ponceau $S$ staining.

\section{RNA isolation and real-time PCR}

The hFOB cells were subjected to RNA extraction by using spin columns (RNeasy; QIAGEN, Hilden, Germany), according to the manufacturer's instructions. RNA $(2 \mu \mathrm{g})$ was reverse transcribed by using the RevertAid First-Strand Synthesis System kit for real-time polymerase chain reaction (Thermo Fisher Scientific, Pittsburgh, PA, USA), according to the manufacturer's protocol. The cDNA was amplified with the SYBR Green PCR master mix kit (Applied Biosystems, Warrington, UK), and the PCR amplification was performed by using the Chromo4 Real-Time PCR Detection System (Bio-Rad Laboratories, Inc.). Running conditions were as follows: incubation at 
$95{ }^{\circ} \mathrm{C}$ for $3 \mathrm{~min}$, and 40 cycles of incubation at $95{ }^{\circ} \mathrm{C}$ for $15 \mathrm{~s}$ and $60^{\circ} \mathrm{C}$ for $30 \mathrm{~s}$. After the last cycle, the melting curve analysis was performed at $55-95{ }^{\circ} \mathrm{C}$ intervals by incremental temperature increases of $0.5^{\circ} \mathrm{C}$.

\section{Detection of RANKL, OPG, and M-CSF by ELISA}

The RANKL, OPG, and M-CSF secretions were measured with an ELISA kit (Quantikine, R\&D Systems, $\mathrm{MN}$, USA), according to the manufacturer's instructions. Cultured hFOB 1.19 cells were uniformly seeded into 6-well culture dishes at a concentration of $2 \times 10^{5}$ cells/well. When the cells became adherent after $24 \mathrm{~h}$, the medium was replaced with a medium containing $50 \mu \mathrm{M}$ alendronate for $48 \mathrm{~h}$. Laser irradiation was subsequently applied three times at 0, 24, and $48 \mathrm{~h}$. The supernatants were collected and ELISA was used to determine the RANKL, OPG, and M-CSF concentrations in each sample at $72 \mathrm{~h}$. The values were determined based on a standard curve set to $450 \mathrm{~nm}$ with a 540-570-nm wavelength correction and expressed as $\mathrm{pg} / \mathrm{ml}$. All of the samples were simultaneously assayed.

\section{Statistical analysis}

A comparative analysis was run by one-way ANOVA with Tukey's post hoc test for cell survivability, RT-PCR, and ELISA (SPSS version 17.0). The $P$ values $<0.05$ were considered as statistically significant.

\section{Results}

Cell survivability following the treatment with alendronate and low-level laser therapy

An hFOB cell survivability assay was performed at 24, 48 , and 72 h with $0,25,50,100,250,500$, and $1000 \mu \mathrm{M}$ alendronate concentrations (Fig. 1a). In the cells treated with alendronate at concentrations of $50 \mu \mathrm{M}$ and higher, the cell survivability significantly decreased after $48 \mathrm{~h}$ $(p<0.05)$. In order to evaluate the effects of LLLT on alendronate-treated cells, the cell survivability was measured at 24, 48, and $72 \mathrm{~h}$ after the laser application (Fig. 1b).

The cell survivability in the alendronate-treated group continuously decreased. After three applications of lowlevel laser (LLL), the cell survivability significantly increased at $72 \mathrm{~h}(p<0.05)$.

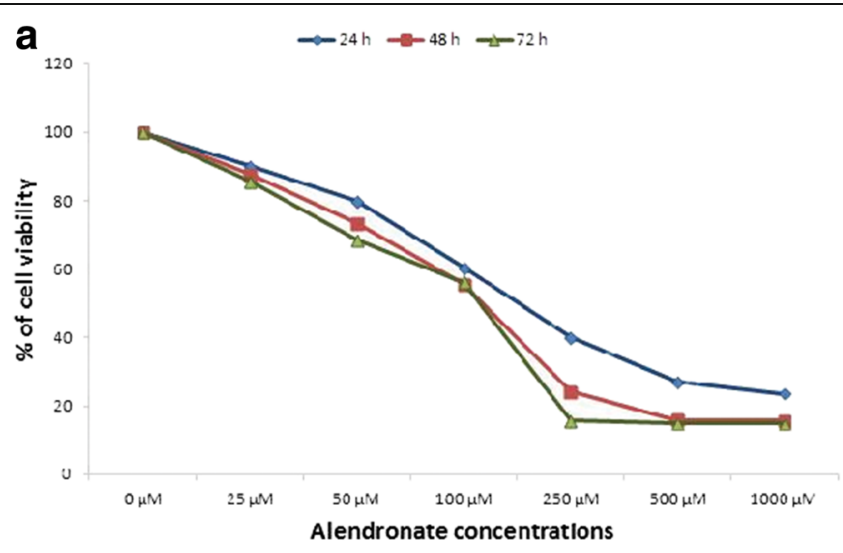

b

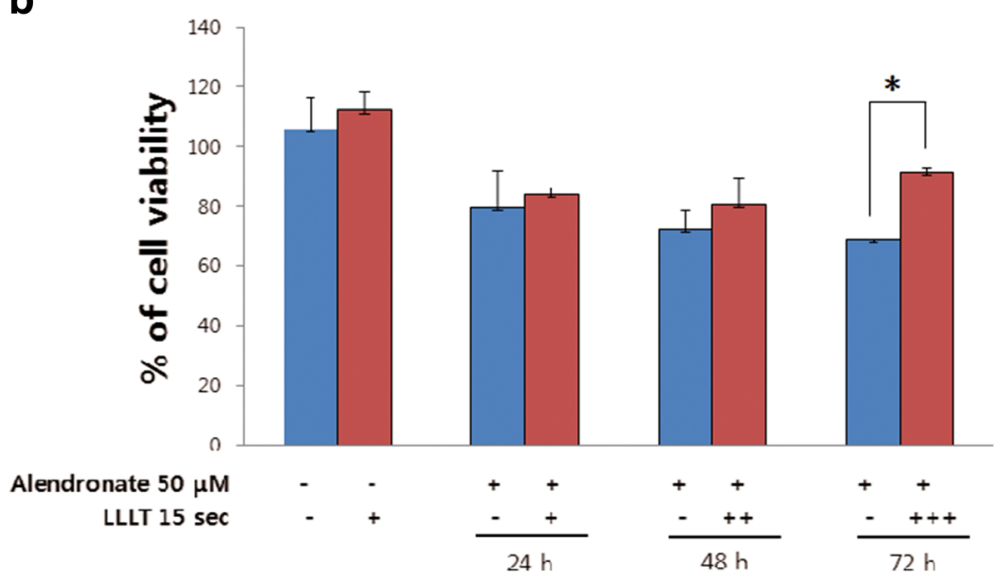

Fig. 1 a Cell viability following treatment with different concentrations of alendronate and LLLT in hFOB 1.19 cells. b Cell viability following treatment with $50 \mu \mathrm{M}$ alendronate and LLLT in hFOB 1.19 cells. (*Statistical significance $(p<0.05)$ compared with alendronate-treated group) 
Effects of alendronate and LLLT on OPG expression Western blot, RT-PCR, and ELISA were used in order to determine the OPG expression. The OPG expression in the alendronate-treated cells decreased more than that of the control group; however, there was no statistical significance (Fig. 2b). In the alendronate cells treated with the laser, the OPG expression increased more than that of the alendronate-treated group; however, the difference was not statistically significant (Fig. 2b, c).

\section{Effects of alendronate and LLLT on RANKL expression}

Western blot, RT-PCR, and ELISA were used in order to determine the RANKL expression, which induces osteoclastogenesis. In the alendronate-treated cells, the RANKL expression decreased more than that of the control group (Fig. 3b). In the alendronate cells treated with the laser, the RANKL expression increased more than that of the alendronate-treated group (Fig. 3b, c).

\section{Effects of alendronate and LLLT on M-CSF expression} Western blot, RT-PCR, and ELISA were performed in order to investigate the M-CSF expression, which is

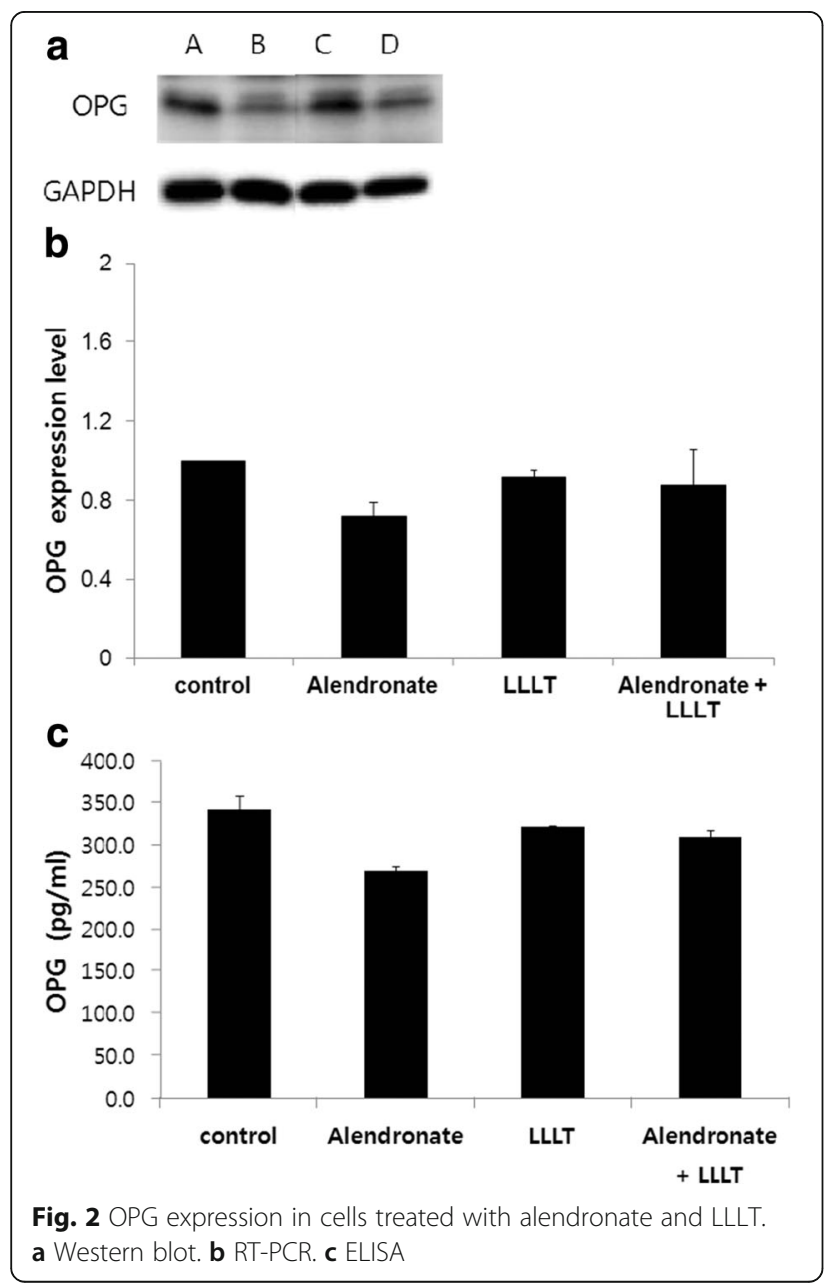

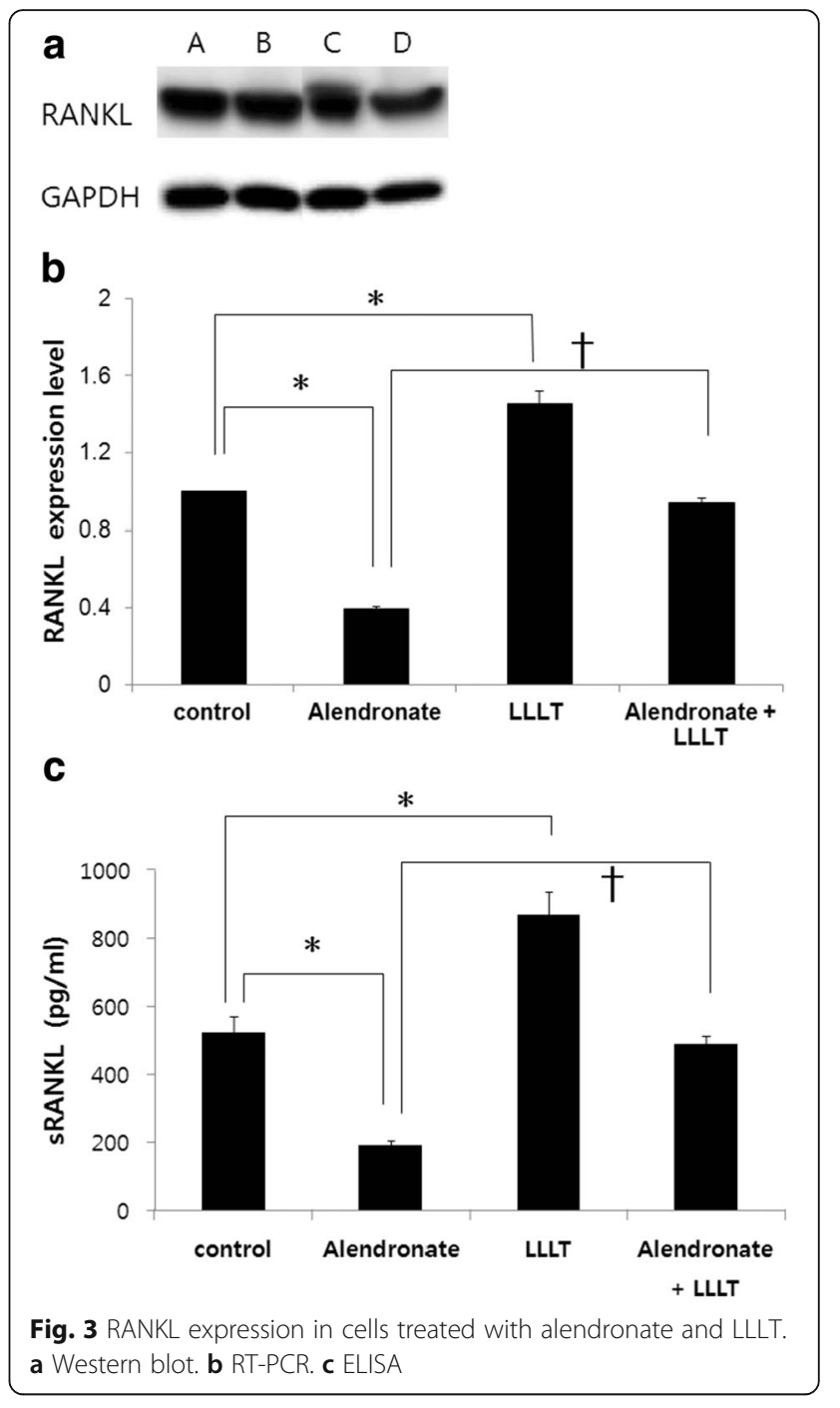

another factor related to osteoclastogenesis. In the cells treated with alendronate, the M-CSF expression decreased more than that of the control group; however, there was no statistical significance (Fig. 4b). In the alendronate cells treated with the laser, the M-CSF expression increased more than that of the alendronate-treated group (Fig. 4b, c).

\section{Discussion}

BPs are the most widely used anti-resorptive drugs for metabolic bone diseases [10]. BPs are pyrophosphatelike structures with two variable regions (R1 and R2) on the carbon atom of the BP molecule attached to the basic P-C-P structure. This allows for variations in the molecular structure and a range of corresponding potencies. BPs are classified according to the chemical group added to the base pyrophosphoric nucleus at the R2 side chain. Alkyl derivatives are the first generation of drugs (e.g., etidronate). The second generation includes 


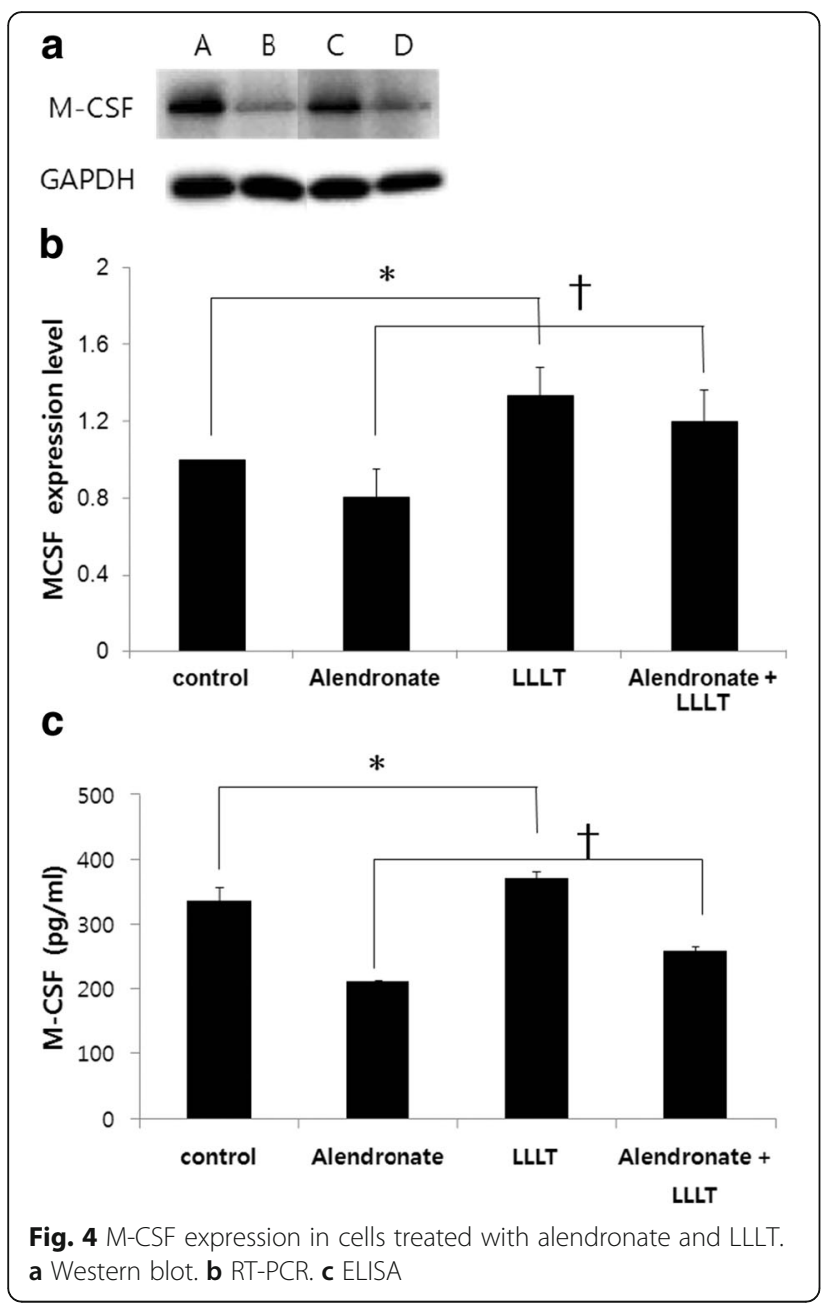

amino-bisphosphonates with a terminal amino group (e.g., alendronate and pamidronate), while the third generation is characterized by a cyclic side chain (e.g., zoledronate). Depending on whether or not nitrogen is attached to the R2 side chain, BPs are classified as nitrogen-containing BPs (NBPs) or non-nitrogen-containing BPs (NNBPs). NBPs (e.g., pamidronate, alendronate, risedronate, ibandronate, and zoledronate) inhibit farnesyl pyrophosphate synthase (FPPS), which is an enzyme in the mevalonate pathway, and block the prenylation of small GTPasesignaling proteins. This results in the accumulation of active unprenylated GTPases in the cytoplasm of the osteoclast, which causes an inappropriate activation of the downstream signaling pathways, thereby leading to the disruption of normal osteoclast function and survival. As a result, NBPs suppress bone resorption through a direct effect on the osteoclasts and their precursors $[11,12]$.

In the present study, we examined the effects of alendronate on osteoblasts. Alendronate is the most widely prescribed oral BP, which is more likely to cause BRONJ. However, the precise mechanism of alendronate in BRONJ remains elusive [13].
The effects of BPs on osteoclasts are well understood, and their toxicity effects on osteoclast are thought to influence the onset of BRONJ. Besides the inhibition of osteoclasts, many complicated events may be related to BRONJ development, and interactions among the bone cells must be considered as a whole [14]. Although the majority of in vitro BP studies have focused on the activities of the osteoclast lineage cells, recent studies have suggested that the presence of osteoblastic family cells is required in order for the anti-resorptive effects of BPs to occur. This effect may depend upon soluble factors that are secreted by the osteoblasts, which inhibit the formation and activity of the osteoclasts [15]. RANKL, OPG, and M-CSF are essential factors that are produced by the osteoblast/stromal cells for osteoclast-osteoblast interactions. RANKL is an important factor in protecting bone resorption, extending the life of osteoclasts, and promoting differentiation. OPG is known as a decoy receptor protein that prohibits osteoclast activation by protecting the function of the receptor activator nuclear factor-kB (RANK), which is involved in osteoclast differentiation by combining with RANKL [16]. The role of OPG is largely associated with an initiation phase, in which OPG counteracts the osteoclastogenic activity of RANKL. During bone formation, osteoclast differentiation is suppressed through the OPG that is produced by the osteoblast [17]. Osteoblasts produce M-CSF, which is required for cell survival in the macrophageosteoclast lineage, and the control of cell migration and reorganization [18]. However, studies on the effects of BPs on osteoblasts are the subject of debate. In addition, the effects of BPs on osteoblastic activities have been sparsely investigated in terms of BRONJ development [19-21]. Knowledge regarding the effects of alendronate on the hFOB cells, particularly in the OPG/RANKL system, is lacking.

In order to address this data gap, we investigated the expressions of RANKL, OPG, and M-CSF in BP-treated hFOB cells. In the cells treated with alendronate at concentrations of $50 \mu \mathrm{M}$ and higher, the cell survivability significantly decreased after $48 \mathrm{~h}$, and there was a strongly negative dose-dependent influence on the viability of the osteoblasts and induced toxic effects in the hFOB cells. Enjuanes et al. [12] reported that high concentrations of alendronate inhibited osteoblast proliferation in the primary hFOB cells and indicated that the drug did not significantly inhibit proliferative effects, as compared to controls at lower concentrations $(\leq 10-$ $5 \mathrm{M})$. Naidu et al. [22] reported that high concentrations of alendronate and zoledronate were cytotoxic and decreased the cell survivability at $72 \mathrm{~h}$, and cytotoxicity leading to cell death was likely to result in osteonecrosis. Our results are similar to these studies and suggest that alendronate at higher concentrations, more than $50 \mu \mathrm{M}$ 
will affect $\mathrm{hFOB}$ cell proliferation and viability significantly after $48 \mathrm{~h}$. We observed that $50 \mu \mathrm{M}$ alendronate appeared to suppress M-CSF and RANKL expressions, and decreased the OPG expression, as compared to the control group. The RANKL expression appeared to be more suppressed than the OPG expression. RANKL expression level was more decreased than OPG or M-CSF in RT-PCR and ELISA result. Appeared by Western blot analysis, OPG, RNAKL, and M-CSF proteins were decreased in alendronate-treated cells.

Therefore, we proposed that the BPs interfere with osteoclastogenesis through regulating mediators (e.g., MCSF, RANKL, and OPG) by inhibition of their expressions. However, Lin et al. [23] found no significant influence on osteoblast RANKL and OPG gene expressions during a 48-h experimental period when investigating alendronate and pamidronate. In contrast, Mackie et al. [24] reported that the RANKL gene expression was inhibited, while the OPG gene expression was not altered by stimulation with pamidronate in an osteosarcoma cell line for 6 days. Although the reasons for these differences have not been completely explained, the distinct effects of various BPs (e.g., pamidronate, zoledronate, and alendronate) and the use of different cell lines (e.g., human vs. rat and primary vs. cancer) could play a role [25]. Additional in-depth studies will be required in order to understand the reasons for these differences.

In medicine and dentistry, diode lasers have been used predominantly in applications that are broadly termed as LLLT or biostimulation [26], and many studies have evaluated the therapeutic effects of LLLT on a broad range of disorders. LLLT applications, which have been promoted by some authors and manufacturers of the LLLT devices, included the acceleration of wound healing, enhancement of the remodeling and repair of bones, restoration of normal neural function following injury, pain attenuation, and modulation of the immune system [27]. Recently, research on the use of LLLs in dentistry has proceeded gradually, and the range of clinical applications has been extended. The term LLL includes soft lasers, mid-lasers, low-energy lasers, and cold lasers. A new international definition considers LLLT to be laser therapies that do not increase tissue temperature over $36.5{ }^{\circ} \mathrm{C}$ or normal body temperature. The wavelength of such lasers is reported to be $500-1200 \mathrm{~nm}$. Recent literatures regarding pre-osteoblast stimulation with red laser were reported [28-31]. We used a $\mathrm{Ga}-\mathrm{As}-\mathrm{Al}$ laser with a wavelength of $808 \mathrm{~nm}$, which is within the prescribed range. It is still unclear as to which of the parameters has the greatest effect on therapeutic efficacy, even though there are information about total energy dose, energy density, and laser spectrum. In this study, the greatest biostimulatory effect was observed when a dose of $3.6 \mathrm{~J} / \mathrm{cm}^{2}$ was used. This may be due to the use of different methodologies, such as different types of cells, experimental timings, and radiation distance.

Many previous studies have demonstrated that LLLT is optimal in tissues under a specific stress, such as hypoxia [32-34], diabetes [35-38], and nutritional deficit [39]. Other previous studies have shown that LLLT may enhance the osteogenic potential of osteoblasts, and may promote metabolic bone activity and bone remodeling [40, 41]. LLLT has recently been used as a supportive technique in BRONJ treatment. Clinical cases that describe the application of LLLT to treat BRONJ have been reported, based on in vivo and in vitro experimental studies that demonstrated a biostimulative effect $[7,42,43]$.

Vescovi et al. [44] reported successful results by using a combined treatment in BRONJ patients with medication plus Er:YAG laser surgery and LLLT. However, there have been no cell culture studies designed to explain the positive results obtained with the LLLT biostimulation in combination with surgery in clinical BRONJ cases. The present study investigated the effects of LLLT in hFOB cells treated with alendronate. The cell survivability significantly increased at $72 \mathrm{~h}$ relative to the alendronate-treated cells after LLT application. Moreover, we observed a significant increase in RANKL and M-CSF expressions, as compared to the cells treated only with alendronate. The results showed that alendronate at a concentration of $50 \mu \mathrm{M}$ appeared to inhibit hFOB cell survivability, and suppress the M-CSF and RANKL expressions, and decreased the OPG expression, as compared to the control group. Moreover, the LLLT increased the RANKL and M-CSF expressions relative to the alendronate-treated cells.

In this study, the greatest biostimulatory effect was observed when a dose of $3.6 \mathrm{~J} / \mathrm{cm} 2$ was used. It may be due to the use of different methodologies, such as different types of cells, experimental timings, and radiation distance. Recently, the choice for an appropriate laser source and standardization of radiation parameters will require further research in order to obtain an optimal result for a low-level laser study.

\section{Conclusions}

The present study was conducted in order to determine if LLLT influences cell survivability and cellular functions in hFOB cells following alendronate exposure. The results showed that alendronate at concentrations of $50 \mu \mathrm{M}$ and higher inhibited hFOB cell survivability. Alendronate at a concentration of $50 \mu \mathrm{M}$ appeared to suppress the M-CSF and RANKL expressions, and decreased the OPG expression, as compared to the control group. Moreover, LLLT increased the RANKL and M-CSF expressions relative to the alendronatetreated cells, thereby resulting in positive effects on 
osteoclastogenesis. These results demonstrated the possibility of LLLT in partially overcoming the inhibitory effects of BP and provide an experimental basis to explain the clinical effects of LLLT as a potential treatment modality for BRONJ.

\section{Authors' contributions}

SHS participated in the design of this study and manuscript revision. BSP, YDK, and UKK participated in the fabrication of the new material. KHK, NRC, IRK, and CHK participated in the laboratory study and data collection. KHK and NRC participated in the data analysis and drafted the manuscript. All authors read and approved the final manuscript.

\section{Competing interests}

The authors declare that they have no competing interests.

\section{Author disclosure statement}

All authors have completed and submitted the ICMJE Form for Disclosure of Potential Conflicts of Interest.

\section{Author details}

'Department of Oral and Maxillofacial Surgery, School of Dentistry, Pusan National University, Beomeo, Mulgeum, Yangsan 626-770, Republic of Korea. ${ }^{2}$ Department of Oral Anatomy and Cell Biology, School of Dentistry, Pusan National University, Beomeo, Mulgeum, Yangsan 626-770, Republic of Korea. ${ }^{3}$ Department of Oral and Maxillofacial Surgery, Dentistry, Dong-A Medical Center, 602-715 Pusan, Republic of Korea.

\section{Received: 4 October 2016 Accepted: 31 October 2016}

Published online: 25 November 2016

\section{References}

1. Rogers MJ, Watts DJ, Russell RG (1997) Overview of bisphosphonates. Cancer 80(8 Suppl):1652-60

2. Coleman RE (2002) Setting new standards in bisphosphonates therapy. Am J Clin Oncol 25(6 Suppl 1):S1-2

3. Marx RE (2003) Pamidronate (Aredia) and zoledronate (Zometa) induced avascular necrosis of the jaws: a growing epidemic. J Oral Maxillofac Surg 61(9):1238-9

4. Ruggiero SL, Mehrotra B, Rosenberg TJ, Engroff SL (2004) Osteonecrosis of the jaws associated with the use of bisphosphonates: a review of 63 cases. J Oral Maxillofac Surg 62(5):527-534

5. Subramanian G, Cohen HV, Quek SY (2011) A model for the pathogenesis of bisphosphonate-associated osteonecrosis of the jaw and teriparatide's potential role in its resolution. Oral Surg Oral Med Oral Pathol Oral Radiol Endod 112(6):744-753

6. Rodan GA, Fleisch HA (1996) Bisphosphonates: mechanisms of action. J Clin Invest 97(12):2692-2696

7. Vescovi P, Merigo E, Manfredi M et al (2008) Nd:YAG laser biostimulation in the treatment of bisphosphonate-associated osteonecrosis of the jaw: clinical experience in 28 cases. Photomed Laser Surg 26(1):37-46

8. Yaakobi T, Maltz L, Oron U (1996) Promotion of bone repair in the cortical bone of the tibia in rats by low energy laser (He-e) irradiation. Calcif Tissue Int 59(4):297-300

9. Dörtbudak O, Haas R, Mallath-Pokorny G (2000) Biostimulation of bone marrow cells with a diode soft laser. Clin Oral Implants Res 11(6):540-545

10. Silverman SL, Maricic M (2007) Recent developments in bisphosphonate therapy. Semin Arthritis Rheum 37(1):1-12

11. Rogers MJ (2003) New insights into the molecular mechanisms of action of bisphosphonates. Curr Pharm Des 9(32):2643-2658

12. Enjuanes $A$, Ruiz-Gaspà $S$, Peris $P$ et al (2010) The effect of the alendronate on OPG/RANKL system in differentiated primary human osteoblasts. Endocrine 37(1):322-328

13. Marx RE (2008) Clinical concerns of alendronate use. J Oral Maxillofac Surg 66(6):1322

14. Rustemeyer J, Bremerich A (2009) Bisphosphonate-associated osteonecrosis of the jaw: what do we currently know? A survey of knowledge given in the recent literature. Clin Oral Investig 14(1):59-64
15. Nishikawa M, Akatsu T, Katayama Y et al (1996) Bisphosphonates act on osteoblastic cells and inhibit osteoclast formation in mouse marrow cultures. Bone 18(1):9-14

16. Udagawa N, Takahashi N, Yasuda H et al (2000) Osteoprotegerin produced by osteoblasts is an important regulator in osteoclast development and function. Endocrinology 141(9):3478-3484

17. Bai S, Kopan R, Zou W et al (2008) NOTCH1 regulates osteoclastogenesis directly in osteoclast precursors and indirectly via osteoblast lineage cells. J Biol Chem 283(10):6509-6518

18. Lagasse E, Weissman IL (1997) Enforced expression of Bcl-2 in monocytes rescues macrophages and partially reverses osteopetrosis in op/op mice. Cell 89(7):1021-1031

19. Walter C, Klein MO, Pabst A, Al-Nawas B, Duschner H, Ziebart T (2010) Influence of bisphosphonates on endothelial cells, fibroblasts, and osteogenic cells. Clin Oral Investig 14(1):35-41

20. Acil Y, Möller B, Niehoff P, Rachko K, Gassling V, Wiltfang J, Simon MJK (2012) The cytotoxic effects of three different bisphosphonates in-vitro on human gingival fibroblasts, osteoblasts and osteogenic sarcoma cells. J Cranio-Maxillofacial Surg 40:e229-e235

21. Peris P, Atkinson EJ, Gössl M, Kane TL, McCready LK, Lerman A, McGregor UI (2013) Effects of bisphosphonate treatment on circulating osteogenic endothelial progenitor cells in postmenopausal women. In Mayo Clinic Proceedings 88:46-55

22. Naidu A, Dechow PC, Spears R, Wright JM, Kessler HP, Opperman LA (2008) The effects of bisphosphonates on osteoblasts in vitro. Oral Surg Oral Med Oral Pathol Oral Radiol Endod 106(1):5-13

23. Lin JM, Callon KE, Lin CQ et al (2007) Alteration of bone cell function by RANKL and OPG in different in vitro models. Eur J Clin Invest 37(5):407-415

24. Mackie PS, Fisher UL, Zhou H, Choong PF (2001) Bisphosphonates regulate cell growth and gene expression in the UMR 106-01 clonal rat osteosarcoma cell line. Br J Cancer 84(7):951-958

25. Idris Al, Rojas J, Greig IR, Van't Hof RJ, Ralston SH (2008) Aminobisphosphonates cause osteoblast apoptosis and inhibit bone nodule formation in vitro. Calcif Tissue Int 82(3):191-201

26. Goldman L, Goldman B, Van Lieu N (1987) Current laser dentistry. Lasers Surg Med 6(6):559-562

27. Nanami T, Shiba H, Ikeuchi S, Nagai T, Asanami S, Shibata T (1993) Clinical applications and basic studies of laser in dentistry and oral surgery. Keio J Med 42(4):199-201

28. Pagin MT, de Oliveira FA, Oliveira RC et al (2013) Laser and light-emitting diode effects on pre-osteoblast growth and differentiation. Lasers Med Sci 31(5):225-229

29. Sabino LG, de Negreiros LMV, Vollet-filho JD, Ferreira J, Tirapelli DPC, Novais PC, Tirapelli LF, Kurachi C, Bagnato VS (2011) Experimental evidence and model explanation for cell population characteristics modification when applying sequential photodynamic therapy. Las Phys Lett 8(3):239-246

30. Peng F, Wu H, Zheng Y, Xu X, Yu J (2012) The effect of noncoherent red light irradiation on proliferation and osteogenic differentiation of bone marrow mesenchymal stem cells. Lasers Med Sci 27(3):645-653

31. Li WT, Leu YC, Wu JL (2010) Red-light light-emitting diode irradiation increases the proliferation and osteogenic differentiation of rat bone marrow mesenchymal stem cells. Photomed Laser Surg 28(1):157-165

32. Pyo SJ, Song WW, Kim IR et al (2013) Low-level laser therapy induces the expressions of BMP-2, osteocalcin, and TGF- $\beta 1$ in hypoxic-cultured human osteoblasts. Lasers Med Sci 28(2):543-550

33. Hirata S, Kitamura C, Fukushima H, Nakamichi I, Abiko Y, Terashita M, Jimi E (2010) Low-level laser irradiation enhances BMP-induced osteoblast differentiation by stimulating the BMP/Smad signaling pathway. J Cell Biochem 111:1445-1452

34. Fujimoto K, Kiyosaki T, Mitsui N, Mayahara K, Omasa S, Suzuki N, Shimizu N (2010) Low-intensity laser irradiation stimulates mineralization via increased BMPs in MC3T3-E1 cells. Lasers Surg Med 42:519-526

35. Dadpay M, Sharifian Z, Bayat M, Bayat M, Dabbagh A (2012) Effects of pulsed infra-red low-level laser irradiation on open skin wound healing of healthy and streptozotocin-induced diabetic rats by biomechanical evaluation. J Photochem Photobiol B 111:1-8

36. Francis-Goforth KN, Harken AH, Saba JD (2010) Normalization of diabetic wound healing. Surgery 147:446-449

37. Hashmi JT, Huang YY, Shama SK, Kurup DB, De Taboada L, Carrol JD, Hamblin MR (2010) Effect of pulsing in low-level light therapy. Lasers Surg Med 42:450-660 
38. Bayat M, Azari A, Golmohammadi MG (2010) Effects of 780-nm low-level laser therapy with a pulsed gallium aluminium arsenide laser on the healing of a surgically induced open skin wound of rat. Photomed Laser Surg 28:465-470

39. Almeida-Lopes L, Rigau J, Zângaro RA, Guidugli-Neto J, Jaeger MM (2001) Comparison of the low-level laser therapy effects on cultured human gingival fibroblasts proliferation using different irradiance and same fluence. Lasers Surg Med 29(2):179-184

40. Khadra M, Lyngstadaas SP, Haanaes HR, Mustafa K (2005) Effect of laser therapy on attachment, proliferation and differentiation of human osteoblast-like cells cultured on titanium implant material. Biomaterials 26(17):3503-3509

41. Kim YD, Kim SS, Hwang DS et al (2007) Effect of low-level laser treatment after installation of dental titanium implant immunohistochemical study of RANKL, RANK, OPG: an experimental study in rats. Lasers Surg Med 39(5):441-450

42. Stübinger S, Dissmann JP, Pinho NC, Saldamli B, Seitz O, Sader R (2009) A preliminary report about treatment of bisphosphonate related osteonecrosis of the jaw with Er:YAG laser ablation. Lasers Surg Med 41(1):26-30

43. Vescovi P, Merigo E, Meleti M, Fornaini C, Nammour S, Manfredi M (2007) Nd:YAG laser biostimulation of bisphosphonate-associated necrosis of the jawbone with and without surgical treatment. Br J Oral Maxillofac Surg 45(8):628-632

44. Vescovi P, Manfredi M, Merigo E et al (2010) Surgical approach with Er:YAG laser on osteonecrosis of the jaws (ONJ) in patients under bisphosphonate therapy (BPT). Lasers Med Sci 25(1):101-113

\section{Submit your manuscript to a SpringerOpen ${ }^{\circ}$ journal and benefit from:}

- Convenient online submission

- Rigorous peer review

- Immediate publication on acceptance

- Open access: articles freely available online

High visibility within the field

- Retaining the copyright to your article

Submit your next manuscript at $\gg$ springeropen.com 